\title{
Peculiarities of differentiation of legal regulation of pharmaceutical workers' labour
}

\author{
Anna Sydorenko and Olena Melnyk \\ Poltava Law Institute of Yaroslav the Wise National Law University, Poltava, Ukraine
}

\begin{abstract}
The paper deals with peculiarities of legal regulation of pharmaceutical workers' labour. Exercising the right to work is determined and analyzed. The authors prove that differentiation originates from special legislation. They determine what globalization is in the modern society. The paper analyzes the differentiation of pharmaceutical workers' labour through the prism of such objective reasons as industry affiliation, working conditions, the nature of labour relations between an employee and an employer, and their content is determined. The study draws attention to the fact that industry affiliation is characterized by the importance of the industry for society and the degree of provision of public health institutions with highly skilled specialists, as well as the production process. The paper determines that working conditions are specific for each industry and workplace. It is proved that pharmaceutical workers have harmful and dangerous working conditions. Working conditions have to satisfy the requirements to the fulfilment of labour duties without life and health hazard. It is analyzed that the nature of labour relations between an employee and an employer are determined by the nature of labour and employment contract term. It is proved that the differentiation of pharmaceutical workers' labour is expressed through special rules, which allows them to exercise their rights and obligations and to enjoy certain guarantees.
\end{abstract}

Key words: unity, differentiation, globalization, pharmaceutical workers, industry affiliation, working conditions, nature of labour relations.

\section{Introduction}

One of the most important tasks of modern labour law is creating conditions for reconciling interests of participants in social and labour relations, protecting rights and legitimate interests of the subjects of labour law. The fulfilment of this task should, first of all, take place by securing proper rights and obligations in statutory acts both internationally and nationally.

Under current conditions of social development, the actual problems of exercising the right to work by a person are caused by gaps in the rules of labour legislation concerning regulation of labour of various categories of employees, inconsistency of the legal principles enshrined in general, and special and local statutory acts. Relations in the labour field are governed by a large number of statutory acts of both international and national legislation, which causes conflicts in the regulation of certain issues related to the implementation of the principle of the right to work. This, in turn, raises the problem of the relevance of the study of the unity and differentiation of legal regulation of labour, which, in our opinion, is one of the main trends in the improvement of labour legislation and lies in the peculiarities of the nature, working conditions, providing different categories of workers with guarantees, privileges and benefits. 
In today's world, the issue of public health remains topical. The right to health is defined by international rules and national legislation of all countries without exception. In the realm of exercising this right, it is interesting to study the legal regulation of pharmaceutical workers' labour since they are the subjects directly assisting in exercising the right to health.

\section{Aim}

The paper is aimed at studying peculiarities of legal regulation of pharmaceutical workers' labour through the prism of labour differentiation in the context of medical reforms in many countries and in drawing conclusions aimed at improving the current legislation.

\section{Material and methods}

Scientific and theoretical studies of scientists, international statutory acts on labour are the empirical foundations of the study. The conducted research caused the need for application of general scientific and special methods of scientific knowledge.

\section{Results and discussion}

International rules and national legislation of most developed countries determine the right to work as a priority and one of the basic rights of every person since it is one of the fundamental rights. The right to work has been enshrined in the main international documents being the basis of legal rules in all countries. Thus, it should be emphasized that the Universal Declaration of Human Rights provides that everyone has the right to work, free choice of work and protection from unemployment [1]. The International Covenant on Economic, Social and Cultural Rights adopted in 1966 contains a similar provision which "includes the right of everyone to the opportunity to gain his living by work which he freely chooses or accepts" [2]. According to scientists, the international document referred to above forms the standards that the member states have to strive for achievement and enforcement but does not impose any legal obligations on them [3, 4].

The right to work is also defined by the International Covenant on Civil and Political Rights [5]. The Resolution of the United Nations General Assembly on "Setting International Standards in the Field of Human Rights" defines a general system of human rights, including the right to work and opportunity to provide for oneself by virtue of such work [6]. This right is also enshrined in the Convention for Protection of Human Rights and Fundamental Freedoms [7], the European Social Charter (Revised) [8], the Community Charter on Fundamental Social Rights of Workers [9], the Charter of Fundamental Rights of the European Union [10] since the basis the development of the social policy of the member states of the European Union is precisely the definition of their citizens' social and labour rights in many other international instruments, including the Conventions and Recommendations of the International Labour Organization, etc. According to the above-mentioned international instruments, exercising the right to work takes place through the principles of freedom of work, free choice of place of work and the duty of governments to ensure measures for exercising the right to work by all able-bodied people without exception.

It should be emphasized that the acts of the European Union contain a clear list of rights which should be laid down as the basis for the development of statutory acts and be respected and observed while implementing the domestic and foreign policies of the member states of the European Union [11]. 
It is necessary to turn attention to the fact that there are a large number of international rules regulating the issue of exercising the right to work by individuals. However, B. Hepple rightly observes that the problem is not in quantity but in quality of the international labour standards since acts adopted in recent years are not aimed at overcoming the negative effects of fulfilling one's work responsibilities and the effects of globalization [12].

We agree that the development of modern labour legislation should meet the new conditions of social development, technologies and other processes within the framework of the modern period of globalization.

The scholars understand globalization as integration and development of the economy, society under the influence of state-of-the-art technologies, economic relations in the society, as well as the development of national and international policies conducted by governments of countries, international organizations, associations of workers and employers and civil society [13].

It should be noted that the problem of improving the legal regulation of labour and closely related relations is primarily due to the need for differentiation. It is with the help of this phenomenon that general rules acquire more specific features, which approximate the real relations between their subjects while exercising the right to work in various fields.

Before considering the issue of differentiation of legal regulation of pharmaceutical workers' labour, it is necessary to answer the question of what the phenomenon of differentiation is since specifics of the legal status of this category of workers are determined by the general rules of labour law expressed in their unity, that are applied to all employees without exception, and special statutory acts, that are characterized by differentiation of legal regulation of labour. As for a legal definition of the notion of differentiation of legal regulation of labour, it is absent in statutory acts.

In French, the term "différenciation" means a division of the whole into parts, forms, degrees. In turn, differentiation should be understood as legal regulation of labour of various categories of workers which is provided for by special legislation, i.e. certain statutory and subordinate acts in which specific conditions of work in various fields of the economy are manifested and there is division of statutory provision in accordance with any labour relations supplementing the general rules of labour law. This concept contributes to exercising the inalienable right to work by individuals.

Legal regulation of pharmaceutical workers' labour is carried out on the ground of unity and differentiation. In this regard, we consider it necessary to disclose the peculiarities of pharmaceutical workers' legal status, to study the legislation on this issue and to determine possible improvements of labour legislation concerning legal regulation of these workers' labour. As pharmaceutical aid is one of the main components of the public health system, its quality depends on a large number of factors. One of them is the specialists' professional level and the procedure for regulating their work.

We understand unity as a single approach to labour regulation. For example, the main statutory act regulating medical and pharmaceutical workers' labour in the Republic of Moldova is the Labour Code of the Republic [14] which is characterized by unity. The act extends to all employees without exception. It determines the unified procedure for employment contract conclusion, grounds and procedure for dismissal, principles of the labour formation, working time, rest time, etc. The Labour Law of the Republic of Latvia and the Labour Code of the Republic of Lithuania are also examples of unity [15]. However, in addition to the general rules, pharmaceutical workers' legal status falls within the following category of differentiation since differentiation of legal regulation of labour is expressed, first of all, through special rules allowing clarifying, expanding and exercising their rights, obligations and guarantees in the workplace by the relevant categories of workers. The legislation of Estonia can be attributed to the category of differentiation of legal regulation of 
labour since there is no single act of labour legislation in this country. Labour relations are regulated by separate laws, regulations and procedures.

Consequently, we can say that legal regulation of pharmaceutical workers' labour is carried out precisely on the grounds of unity and differentiation, which are interrelated categories. The problem of differentiation is of particular importance in the study since it provides an opportunity to take into account the specifics of different groups of relations. Namely, peculiarities of pharmaceutical workers' legal status are to be considered through the prism of the grounds for differentiation which are divided into two groups: subjective and objective. Particular attention should be paid to the objective reasons. Among the main objective grounds for differentiation of legal regulation of pharmaceutical workers' labour, it is necessary to highlight industry affiliation, working conditions caused by labour specifics, the nature of labour relationship between an employee and an employer. To characterize the objective grounds for differentiation of legal regulation of pharmaceutical workers' labour, it is appropriate to analyze each of them.

The first reason to be observed is the industry affiliation of an enterprise, institution or organization. For this reason, the importance of the industry and a degree of providing a particular enterprise, institution or organization with highly skilled specialists are taken into account. As for the importance of the industry, public health has a significant role in society since each person has the inalienable and indispensable right to health protection.

As far as pharmaceutical workers' qualifications are concerned, the degree of such qualifications in public health is taken into account even more than in any other field and is determined by the level of professional training, practical experience, individual qualities due to the fact that pharmaceutical workers' labour has to do with human life and health. Referring to the Conclusions of the World Health Organization's Second Meeting (held in Tokyo in 1993, "The Role of the Pharmacist: Quality Pharmaceutical Services - Benefits for Governments and the Public"), the concept of pharmaceutical services were formed, according to which the patients' interests have to be in the centre of the pharmaceutical workers' activities given such their proper training.

It should be noted that under the modern conditions of social development, qualified pharmaceutical workers should understand both organizational and economic issues as well as the modern regulatory framework which is changing rapidly enough. They should know the current trends and processes of the pharmaceutical market, understand the purpose, goals, objectives of the institution they work at, comply with the requirements of pharmaceutical activity, bear the corresponding responsibility for the quality of such activities, adhere to appropriate ethical standards in their work, etc.

Training pharmaceutical workers in various countries is carried out differently. Thus, in European countries, higher education is obtained in accordance with the provisions of the Bologna Process. For example, pharmacists' diplomas issued by all European countries are recognized in such countries as the Czech Republic, Poland and Germany. The practice of Poland is interesting enough as students there are granted the right to choose English-language curricula and their curricula exclude subjects not applicable for future professionals. Their special feature is a fairly long period of practice and internship in Germany or France. In Bulgaria, there are training centres set up by pharmacies and pharmaceutical firms. Practice of the United States is different as there is not a federal law on pharmaceutical education and qualifications, so each state has its own requirements for such education. It should be noted that the International Pharmaceutical Federation with the World Health Organization and UNESCO are constantly developing and improving the Global Competency Framework for services provided by pharmaceutical workforce. One of its versions has been developed on the basis of standards, legislative acts and recommendations of pharmaceutical workers' associations. It is based on the areas as follows: 
scientific and managerial knowledge, public health and patient orientation, system and applied competences. The global model of pharmaceutical workforce's competences is the basis of Continuing Professional Development, adopted by the majority of countries and the professional standards that are to be followed by such countries rest on it.

Industry affiliation is characterized by the fact that employees perform work only within a certain industry and in accordance with special regulations. Pharmaceutical workers' legal status includes their professional rights, duties, and responsibilities. For example, the right to rest is fixed in the first place in one of the main international documents, namely, Article 24 of the Universal Declaration of Human Rights, which states that "everyone has the right to rest and leisure, including reasonable limitation of working hours and periodic holidays with pay" [1]. Taking into consideration the fact that pharmaceutical workers have harmful and dangerous working conditions, the length of their holidays is prolonged in comparison with other categories of employees.

Furthermore, our attention should be paid to Directive 2003/88/EC of the European Parliament and of the Council of 4 November 2003 concerning certain aspects of the organization of working time which states that long working hours and inadequate rest periods may result in fatigue or other irregular working patterns and lead to further accidents, significant errors, cause stress for a person working in this mode and lead to health risks [16]. It should be noted that pharmaceutical workers often work overtime and this problem is drawn attention to in the Report of the Health and Medical Committee of the International Labour Organization. It refers to a wide range and diversity of the rules for overtime work for medical and pharmaceutical workers depending on the required amount of services provided to the public, as well as the traditions and culture of health care in a country or region [17]. In addition, certain limitations are imposed on pharmaceutical workers in the performance of their duties, for example, the prohibition on receiving unlawful benefits from their activities, providing inaccurate information about the availability of medicines, etc., for which they can be brought to a certain degree of responsibility.

Consequently, industry affiliation as the basis for differentiation is determined, first of all, by the nature of the production process.

Working conditions are the next reason for differentiation of legal regulation of pharmaceutical workers' labour. Each type of specific labour conditions requires labour costs and appropriate efforts. Working conditions are specific to each production, each workplace since they affect their body state, health and work capacity.

As for the issue of normative consolidation of the concept of adequate and safe working conditions, the main international rules are contained in the regulations as follows: the International Covenant on Economic, Social and Cultural Rights, the European Social Charter (Revised), the International Labour Organization Convention No. 155: Occupational Safety and Health, 1981, Occupational Safety and Health Recommendation, 1981 (No. 164) concerning Occupational Safety and Health and the Work Environment [2, 8, 18].

As noted above, pharmaceutical workers deal with harmful and dangerous factors. The factors causing damage to human life and health should be understood as harmful working conditions. Researchers of the European Agency for Safety and Health at Work conclude that as a result of special conditions of work, medical and pharmaceutical workers are exposed to occupational risks such as: biological (when performing duties imposed on pharmaceutical workers, they are in contact with a large number of people as a result of which they may become infected or have other illnesses); chemical (pharmaceutical workers contact with medications and remedies that can cause damage to their health; they are influenced by disinfectants that can cause allergies, etc.); physical (there are effects of ionizing radiation, uncomfortable climate, insufficient lighting of the workplace and other factors affecting this category of employees in the performance of their professional duties); psychological (they 
are characterized by emotional and psychological stress); ergonomic risks (they suffer long standing and constant walking in the workplace) [19].

It should be emphasized that working conditions have to meet the requirements for carrying out employment duties without life and health hazards, avoid fatigue and ensure high labour productivity. Researchers from the World Health Organization point out that an unsatisfactory working environment has a negative impact on providing the public health sector with human resources and quality of medical and pharmaceutical care as the work environment is a factor of great importance for employing and retaining human resources [20]. As for labour remuneration, differentiation of wages for this category of workers, depending on working conditions, should increase since it is intended to compensate for additional labour costs and create material benefits for workers having harmful working conditions.

It should also be noted that the impact criteria of the working environment, first of all, characterize special conditions of pharmaceutical workers' labour and derive from the workers' right to proper, safe and healthy working conditions. The above criteria are characterized by intra-industry differentiation of legal regulation of labour.

The next reason for differentiation of legal regulation of pharmaceutical workers' labour is the nature of labour relationship between an employee and an employer. The nature of labour relations should be understood as a kind of work as well as a period which necessitates issuing differentiated legal rules [21]. Such differentiation is characterized by a special order of arising and terminating labour relations. In the case of pharmaceutical workers, labour relations usually arise on the basis of an employment contract in accordance with the law. Consequently, their differentiation based on the nature of labour relations is more specific when concluding fixed-term employment contracts.

\section{Conclusion}

Legal regulation of pharmaceutical workers' labour is expressed through unity and differentiation. The latter is manifested in a significant number of statutory acts since special legislation reflects the peculiarities of work, both objective and subjective.

A fairly large number of statutory acts and international standards do not always speak for their quality. We are sure that, as far as pharmaceutical workers' labour is concerned, common standards for education, training, performance evaluation and adequate working conditions should be binding, enforceable and developed to amend national legislation of all countries.

As for working conditions, they are determined by relevant criteria of production and labour process. Without the creation of proper production and social conditions, introduction of a new system of labour remuneration, protection of medical and pharmaceutical workers, the situation within public health can only deteriorate. Since a number of private pharmacies is increasing, the turnover of personnel is quite significant.

Differentiation of legal regulation of pharmaceutical workers' labour is intended to provide additional privileges, benefits and guarantees that are not clearly regulated by law. In our opinion, it would be reasonable to systematize a significant number of statutory acts into one general document for more rational use since the development of modern labour law should take place within the framework of modern globalization.

\section{References}

[1] Universal Declaration of Human Rights. Available at: http://www.un.org/ en/universal-declaration-human-rights/ 
[2] International Covenant on Economic, Social and Cultural Rights. Available at: www. ohchr.org/en/professionalinte-rest/pages/ceser.aspx

[3] A. Robertson Human Rights in the world. Manchester (1972)

[4] D. Trubec Economic, Social and Cultural Rights in the Third World: Human Rights and Human Needs Programs // Human Rights in International Law: Legal and Policy Issues: Oxford (1984)

[5] International Covenant on Civil and Political Rights. Available at: www.ochr. org/en/professionalinterest/pages/ccpr . aspx

[6] A/Res/41/120 Sitting International standards in the field of human rights The General Assembly. Available at: www .un.org/ga/res/41/a41r120.htm

[7] European Convention on Human Rights. Available at: www.en.m.wikipedia. org/wiki/European_Convention_on_Human_Rights

[8] European Social Charter (Revised). Available at: www.en.m.wikipedia.org/wiki/ European_Social_Charter

[9] Community Charter of the Fundamental Social Rights of Workers. Available at: www . eurofocend . europa.eu/observatories/eurwork/industrialrelations-dictionary/community-charter-of-the-fundamental-socialrights-of-workers

[10] Charter of Fundamental Rights of the European Union. Available at: www.en.m. wikipedia.org/wiki/Charter_of_Fundamental_Rights_of_the_European_ Union

[11] Communication from the Commission "On the Charter of Fundamental Rights of the European Union" COM (2000) 559 final. Brussels, (13.09.2000)

[12] B. Hepple. Labour Laws and Global Trade. Hart Publishing. Oxford and Portland, Oregon (2005)

[13] B.Gunter, R. Hoeven, The Social dimension of globalization; A review of the literature// International labour Review, vol.143, No. - 1-2, Geneva (2004)

[14] Labour Code of the Republic of Moldova. Available at: www.cis-legistation. com/document.fwsc?rgn $=3836$

[15] Republic of Lithuania Labour Code. Available at: www .e-seimas . Irs. It

[16] Directive 2003/88/EC of the European Parliament and of working time. Available at: www.eur.-lex.europa.eu/smartapi/cgi/sga_doc?smartapi ! cebxapi ! pred!CELEXnum doc@lg =en\&numdoc $=3200340088 \& \mathrm{midel}=$ guichetf

[17] International Labour Organization Standing Service, First Session, Geneva (1992)

[18] Occupational Safety and Health Convention, 1981 (No.155). Available at: www.ilo.org/dyn/normlex/en/f?p=NORMLEXPUB : 12100:0: : NO : :p12100_ instrument_id:312300

[19] European Agency of Safety and Health at Work (OSHA). Health and Safety of Healthcare Staff. Available at: www.osha.europa.eu/en/sector/ healthcare.

[20] К. Вискоу, Т. Альбрехт, де К. Прието Как создать для медицинских работников привлекательную и благоприятную рабочую среду // Мат.конф. «Инвестирование в кадровые ресурсы здравоохранения Европы завтрешнего дня: возможности для инноваций и сотрудничества» (Ла-Юльп, 9-10 сентября 2010)

[21] С.А. Иванов Советское трудовое право: вопросы теории / С.А. Иванов, Р.З. Лившиц, Ю.П. Орловский. - М.: Наука (1978) 